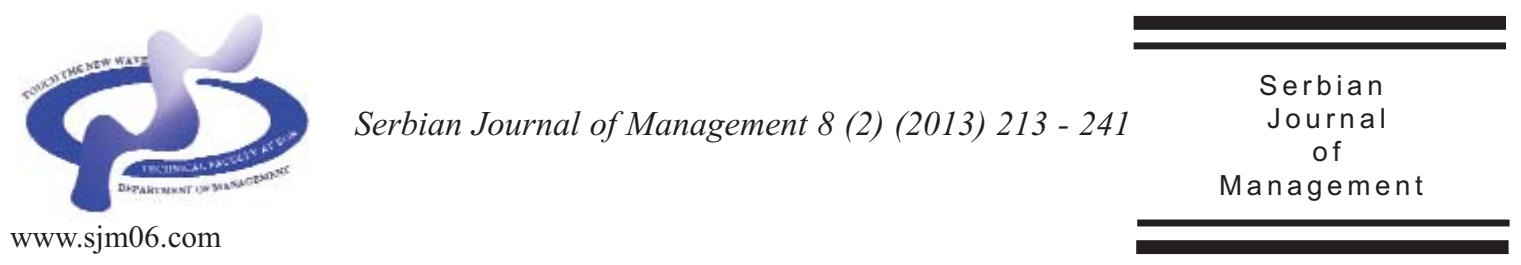

\title{
COMPARATIVE ANALYSIS OF SOME PROMINENT MCDM METHODS: A CASE OF RANKING SERBIAN BANKS
}

\author{
Dragisa Stanujkic*, Bojan Đorđević and Mira Đorđević \\ Faculty of Management Zajecar, Megatrend University, Park suma "Kraljevica" bb, \\ 19000 Zajecar, Serbia
}

(Received 17 April 2013; accepted 16 October 2013)

\begin{abstract}
In the literature, many multiple criteria decision making methods have been proposed. There are also a number of papers, which are devoted to comparison of their characteristics and performances. However, a definitive answer to questions: which method is most suitable and which method is most effective is still actual. Therefore, in this paper, the use of some prominent multiple criteria decision making methods is considered on the example of ranking Serbian banks. The objective of this paper is not to determine which method is most appropriate for ranking banks. The objective of this paper is to emphasize that the use of various multiple criteria decision making methods sometimes can produce different ranking orders of alternatives, highlighted some reasons which lead to different results, and indicate that different results obtained by different MCDM methods are not just a random event, but rather reality.
\end{abstract}

Keywords: MCDM, SAW, MOORA, GRA, CP, VIKOR, TOPSIS

\section{INTRODUCTION}

The multiple criteria decision making (MCDM) can be generally described as the process of selecting one from a set of available alternatives, or ranking alternatives, based on a set of criteria, which usually have a different significance.
During the second half of the 20th century, MCDM was one of the fastest growing areas of operational research and because of them many MCDM methods have been proposed. From many of the proposed MCDM methods, we shall state some of the most prominent, such as: Simple Additive Weighting (SAW) method (MacCrimon,

\footnotetext{
* Corresponding author: dragisa.stanujkic@fmz.edu.rs
}

DOI:10.5937/sjm8-3774 
1968), Compromise programming (Zeleny, 1973; Yu, 1973), Analytic Hierarchy Process (AHP) method (Saaty, 1980), Technique for Ordering Preference by Similarity to Ideal Solution (TOPSIS) method (Hwang \& Yoon, 1981), Preference Ranking Organisation Method for Enrichment Evaluations (PROMETHEE) method (Brans \& Vincke, 1985), Grey Relational Analysis (GRA) proposed by Deng (1989) as part of Grey system theory, ELimination and Choice Expressing REality (ELECTRE) method (Roy, 1991), COmplex PRoportional ASsessment (COPRAS) method (Zavadskas et al., 1994), VIKOR (VIsekriterijumska optimizacija i KOmpromisno Resenje in Serbian, means Multicriteria Optimization and Compromise Solution) method (Opricovic, 1998), Additive Ratio Assessment (ARAS) method (Zavadskas \& Turskis, 2010), Multi-Objective Optimization on the basis of Ratio Analysis (MOORA) method (Brauers \& Zavadskas, 2006) and Multi-Objective Optimization by Ratio Analysis plus Full Multiplicative Form (MULTIMOORA) method (Brauers \& Zavadskas, 2010a).

In the past, these methods have been used to solve many problems, which are documented in many professional and scientific journals. Numerous prominent papers presented research in MCDM, which is why we omit the reference to them in this paper.

The above-mentioned MCDM methods transform multiple criteria decision-making process, i.e., Multiple Criteria optimization, in a single criterion decision-making optimization, which is much easier to solve. A number of authors have been identifying different phases (stages) in MCDM process, from which, in order to more clearly point out the objectives of this study, the following phases are emphasized:

- criteria weights determination,

- normalization,

- aggregation, and

- selection.

A typical MCDM problem can be precisely presented in the following form:

$$
\begin{aligned}
& D=\left[x_{i j}\right]_{m \times n} \\
& W=\left[w_{j}\right]_{n}
\end{aligned}
$$

where $D$ is decision matrix, $x_{i j}$ is performance of $i$-th alternative with respect to $j$-th criterion, $W$ is weight vector, $w_{j}$ is weight of $j$-th criterion, $i=1,2, \ldots m ; m$ is the number of compared alternatives, $j=1,2, \ldots$, $n ; n$ is the number of the criteria.

Information stored in a decision matrix is usually incommensurable, i.e. performance ratings in relation to different criteria are usually expressed using different units of measure. Therefore, data should be transformed into comparable values, using a normalization procedure. For normalization, numerous procedures, also known as normalization methods, have been formed. A comprehensive overview of some normalization procedures were given by Zavadskas and Turskis (2008).

Evaluation criteria involved in the MCDM models can be classified in several ways. In this paper two, very significant classification, of evaluation criteria are considered.

In relation to required direction of optimization, there are two types of evaluation criteria, namely:

- benefit type criteria, i.e., the higher rating is better; and,

- cost type criteria, i.e., the lower rating is better.

Evaluation criteria can also be classified as subjective and objective. Subjective 
criteria have a qualitative nature, i.e., performance ratings of these criteria are rather expressed using quantitative values, often using linguistic variables. In contrast, objective criteria have a quantitative nature, i.e., the performance ratings of these criteria are rather expressed using quantitative values, which is why performance ratings of these criteria can be much more precisely determined.

In MCDM, evaluation criteria usually have different importance (weights), and it is also important that weights of criteria often have a large impact on selection of the most acceptable alternative.

$\mathrm{N}$-dimensional information, stored in a MCDM model, can be transformed into onedimensional using MCDM methods. As is mentioned above, over time, many MCDM methods were proposed. They differ in the approach used to determine the most appropriate alternative, that is, they have different aggregation procedures, use different normalization methods and have different treatment for the cost and benefit criteria.

Therefore, 'Which is the best method for a given problem?' has become one of the most important and challenging questions (Triantaphyllou, 2000). However, the question 'Whether all MCDM methods give the same results?' is also important and actual too.

In the scientific and professional journals many significant papers are published where the comparison of some of the MCDM methods was presented, and the results achieved by their application to the case of solving real-world problems. From many, following are emphasized here: Aghajani et al. (2012), Zolfani et al. (2012), Antucheviciene et al. (2011), Savitha and Chandrasekar (2011), Podvezko (2011),
Zavadskas et al. (2010b), Ginevicius et al. (2010b, 2008), Ginevicius and Podvezko (2009), Caterino et al. (2009), Opricovic and Tzeng (2004).

In this paper, one case study of ranking Serbian banks was considered, using some of the most prominent MCDM methods. This paper examines comparison of results that were achieved using these methods.

Therefore, this paper is organized as follows: In section 2 of this paper, one brief review of some of the most prominent MCDM method is given. In section 3, a case study of ranking Serbian banks, based on objective criteria, is considered. After that, in section 3, several variants of discussed case study are discussed with the aim to determine whether different normalization methods, different aggregation procedures and different criteria weight have impact on the selection of the most acceptable alternative, or a ranking order of the considered alternatives. Finally, section 4 presents conclusions.

\section{A BRIEF COMPARATIVE OVERVIEW OF SOME OF THE MOST PROMINENT MCDM METHODS}

In this section, a brief comparative overview of some prominent MCDM methods is presented. In order to perform their clearer and more precise comparison, some labels in formulas or parts of formulas are adjusted with accepted style.

From many methods which can be used for selecting and/or ranking different alternatives, in this paper, we consider following: SAW, ARAS, COPRAS, MOORA, GRA, CP, VIKOR and TOPSIS method.

One of main objectives that had been 
planned as a result of this study was the formation of a simple to use MCDM model for ranking commercial banks. Therefore, in this study the MCDM methods that require significant user interaction during problem solving was process omitted, such as ELECTRE and PROMETHEE methods. This is the reason why the AHP method was also omitted. However, the pairwise comparison approach, taken from the AHP method was used to determine the weights of criteria.

\subsection{Simple Additive Weighting (SAW)}

Simple additive weighting (SAW) method is probably the simplest, best known and formerly often used MCDM method. The SAW method uses a simple aggregation procedure, which can be presented using the following formula:

$Q_{i}=\sum_{j=1}^{n} w_{j} r_{i j}$,

where $Q_{i}$ is overall ranking index of $i$-th alternative; $w_{j}$ is weight of $j$-th criterion, $r_{i j}$ is normalized performance of $i$-th alternative with respect to $j$-th criterion, $i=1,2, \ldots m$; and $j=1,2, \ldots, n$.

In SAW method, the alternatives are ranked on the basis of their $Q_{i}$ in ascending order, and the alternative with the highest value of $Q_{i}$ is the best ranked. The best ranked, or the most preferable, alternative, based on the SAW method, $A^{*}{ }_{S A W}$ can be determined using the following formula:

$A_{S A W}^{*}=\left\{A_{i}=\max _{i} Q_{i}\right\}$.

The aggregation procedure in SAW method makes no difference between cost and benefit type criteria. Therefore, cost type criteria must be transformed into benefit type criteria during normalization.

Formerly, this form of transformation was often stated as a weakness of SAW method. However, in some actual fuzzy extensions of prominent MCDM methods, cost type criteria also are transformed into benefit type criteria, such as in Saremi et al. (2009), Mahdavi et al. (2008), Wang and Elhag (2006).

SAW method can be used with different normalization procedures. Linear scale transformation - Max method is probably the most frequently used normalization procedure, but there are also other approaches.

Some typical normalization procedures, used in the SAW method, are given below:

\section{a. Linear Scale Transformation, Max method}

$r_{i j}= \begin{cases}x_{i j} / x_{j}^{+} ; & j \in \Omega_{\max } \\ x_{j}^{-} / x_{i j} ; & j \in \Omega_{\min }\end{cases}$

\section{b. Linear Scale Transformation - Sum} method

$r_{i j}= \begin{cases}x_{i j} / \sum_{i=1}^{n} x_{i j} ; & j \in \Omega_{\max } \\ \left(1 / x_{i j}\right) / \sum_{i=1}^{n}\left(1 / x_{i j}\right) ; & j \in \Omega_{\min }\end{cases}$

c. Vector normalization

$r_{i j}= \begin{cases}x_{i j} /\left(\sum_{i=1}^{n} x_{i j}^{2}\right)^{1 / 2} ; & j \in \Omega_{\max } \\ 1-\left(x_{i j} /\left(\sum_{i=1}^{n} x_{i j}^{2}\right)^{1 / 2}\right) ; & j \in \Omega_{\min }\end{cases}$

d. Linear Scale Transformation, MaxMin method 


$$
r_{i j}= \begin{cases}\frac{x_{i j}-x_{j}^{-}}{x_{j}^{+}-x_{j}^{-}} ; & j \in \Omega_{\max } \\ \frac{x_{j}^{+}-x_{i j}}{x_{j}^{+}-x_{j}^{-}} ; & j \in \Omega_{\min }\end{cases}
$$

where $x_{j}^{+}$is the largest performance ratings and $x_{j}^{-}$is the smallest performance rating of $j$-th criterion, $\Omega_{\max }$ and $\Omega_{\min }$ are sets of benefit and cost criteria, respectively.

As already stated, SAW method was previously frequently used. However, the usage of some recent MCDM methods significantly reduced the use of SAW method, but this simple and effective MCDM method is not forgotten. Moreover, it continues to be developed and used, as proven by its fuzzy and grey extensions, such as: Chen (2012), Turskis et al. (2010), Chou et al. (2008).

SAW method and its extensions are also frequently used in the case of application and comparison of several MCDM methods, such as in Zolfani et al. (2012), Chen (2012), Turskis et al. 2010.

\section{2. (ARAS) A new Additive Ratio ASessment}

A new additive ratio assessment (ARAS) method is newly proposed MCDM method. In this method, the most acceptable alternative is determined on the basis of degree of utility $Q_{i}$, which can be calculated using the following formula:

$Q_{i}=\frac{S_{i}}{S_{0}} ; i=1,2, \ldots, m$

where $S_{i}$ is overall performance index of $i$-th alternative, $S_{0}$ is overall performance index of optimal alternative, and $S_{0}$ usually has a value which is 1 .

The alternatives are ranked on the basis of their $Q_{i}$ in ascending order, and the alternative with the highest value of $Q_{i}$ is the best ranked. The best ranked alternative, based on the ARAS method, $A^{*}{ }_{A R S}$ can be determined using the following formula:

$A_{A R S}^{*}=\left\{A_{i}=\max _{i} Q_{i}\right\} ; i=1,2, \ldots, m$.

The specificity of ARAS method, compared to other methods, is the introduction of the optimal alternative $A_{0}$. The performances of the optimal alternative are determined on the basis of decision makers' preferences. If the decision maker has no preference about some criterion, its optimal performance is determined as follows:

$x_{0 j}=\left\{\begin{array}{ll}\max _{i} x_{i j} ; & j \in \Omega_{\max } \\ \min _{i} x_{i j} ; & j \in \Omega_{\min }\end{array}\right.$.

The ARAS method uses the same aggregation procedure as the SAW method, and therefore the overall performance index of any alternative can be determined as follows:

$$
S_{i}=\sum_{j=1}^{n} w_{j} r_{i j} .
$$

The normalized performance ratings in ARAS are calculated by using the following formula:

$r_{i j}=\left\{\begin{array}{ll}\frac{x_{i j}}{\sum_{i=0}^{m} x_{i j}} ; & j \in \Omega_{\max } \\ \frac{1 / x_{i j}}{\sum_{i=0}^{m} 1 / x_{i j}} ; & j \in \Omega_{\min }\end{array}\right.$.

The ARAS method can be classified as an effective and easy to use MCDM method. Although it is newly proposed, it has been applied to solve various decision-making 
problems, and its fuzzy and grey extension have also been proposed, named ARAS-F (Turskis \& Zavadskas, 2010b) and ARAS-G (Turskis \& Zavadskas, 2010a). From many papers where the use of ARAS method and its extensions is discussed, just few are mentioned here: Zavadskas et al. (2012), Turskis et al. (2012), Kersuliene and Turskis (2011), Susinska et al. (2011), Bakshi and Sarkar (2011).

\section{3. (COPRAS) COmplex PRoportional ASsessment}

Complex proportional assessment (COPRAS) method, compared to previous methods, has slightly more complex aggregation procedure, but it does not require transformation of cost to benefit type criteria. The overall ranking index, of each alternative, can be calculated using the following formula:

$Q_{i}=S_{+i}+\frac{S_{-\min } \sum_{i=1}^{m} S_{-i}}{S_{-i} \sum_{i=1}^{m} \frac{S_{-\min }}{S_{-i}}}$,

where

$S_{+i}=\sum_{j \in \Omega_{\max }} w_{j} \cdot r_{i j}$,

$S_{-i}=\sum_{j \in \Omega_{\min }} w_{j} \cdot r_{i j}$,

$S_{-\min }=\min _{i} S_{-i}$.

The Formula (13) can be also written in following simplified form:

$Q_{i}=S_{+i}+\frac{\sum_{i=1}^{m} S_{-i}}{S_{-i} \sum_{i=1}^{m} \frac{1}{S_{-i}}}$.

The alternatives, by COPRAS method, are ranked on the basis of their $Q_{i}$, and the alternative with the highest value of $Q_{i}$ is the best ranked. The best ranked alternative, based on the COPRAS method, $A^{*}{ }_{C P S}$ can be determined using the following formula:

$$
A_{C P S}^{*}=\left\{A_{i}=\max _{i} Q_{i}\right\}
$$

For normalization, COPRAS method uses linear transformation - Sum method, without transformation of cost to benefit type criteria. The normalized performance ratings in COPRAS are calculated using the following formula:

$r_{i j}=\frac{x_{i j}}{\sum_{i=1}^{n} x_{i j}}$.

Description of COPRAS methods and possibilities of its application are published in a large number of papers, such as: Zavadskas et al. (2001), Zavadskas et al. (2004), Kaklauskas et al. (2005), Kaklauskas et al. (2006).

As for other MCDM methods, fuzzy and grey extension is also proposed for COPRAS method. Fuzzy extension of COPRAS method, COPRAS-F method was introduced by Zavadskas and Antucheviciene (2007), and it used to analyze abandoned building's regeneration alternatives in Lithuanian rural areas. Zavadskas et al. (2008a) proposed a grey extension of COPRAS methods, called GOPRAS-G method, and used it to select dwelling house walls, project managers (Zavadskas et al. 2008b), contractors (Zavadskas et al. 2008c), and so on.

Since then, the COPRAS method and its extensions has been applied for solving decision-making problems. As some significant examples of applying COPRAS and COPRAS-G method can be mentioned: 
Banaitiene et al. (2008), Zavadskas et al. (2008a; 2008b; 2010a), Mazumdar et al. (2010), Podvezko et al. (2010) and Madhuri et al. (2010).

A significant number of papers published in the last two years indicate that the COPRAS method is very actual MCDM method. From many papers few are mentioned here, such as: Zavadskas et al. (2011), Antucheviciene and Zavadskas (2012), Chatterjee and Chakraborty (2012), Fouladgar et al. (2012) and Popovic et al. (2012).

\section{4. (MOORA) The Multi-Objective Optimization by Ratio Analysis}

The multi-objective optimization by ratio analysis (MOORA) method consists of two parts, which are named: Ratio system approach and Reference point approach. These two parts are based on the same type of normalization.

Ratio system approach. The basic idea of the Ratio system approach of the MOORA method is to determine the overall performance index of alternative as the difference between sums of weighted normalized performance of benefit and cost criteria, as follows:

$$
Q_{i}=\sum_{j \in \Omega_{\max }} w_{j} r_{i j}-\sum_{j \in \Omega_{\min }} w_{j} r_{i j} .
$$

The alternatives are ranked on the basis of their $S_{i}$ in ascending order, and the alternative with the highest value of $S_{i}$ is the best ranked. The best ranked alternative, based on the Reference point approach of the MOORA method, $A^{*}{ }_{\text {MRS }}$ can be determined using the following formula:

$$
A_{M R S}^{*}=\left\{A_{i}=\max _{i} Q_{i}\right\} \text {. }
$$

Reference point approach. After considering the most important reference point metrics, Brauers and Zavadskas (2006) emphasize that the min-max metric is the best choice amongst them. Therefore, for optimization based on the reference point approach Brauers and Zavadskas (2006) proposed the following formula:

$$
\min _{i}\left\{\max _{j}\left(w_{j}\left|r_{j}-r_{i j}\right|\right)\right\} \text {. }
$$

The best ranked alternative, based on Reference point approach of the MOORA method, $A^{*}{ }_{\text {MRP }}$ can be determined using the following formula:

$$
A_{\text {MRP }}^{*}=\left\{A_{i}=\min _{i}\left\{\max _{j}\left(w_{j}\left|r_{j}-r_{i j}\right|\right)\right\}\right\} .
$$

For normalization, MOORA method uses vector normalization procedure, without transformation of cost to benefit type criteria. The normalized performance ratings in MOORA method are calculated using the following formula:

$$
r_{i j}=\frac{x_{i j}}{\left(\sum_{i=1}^{n} x_{i j}\right)^{1 / 2}} .
$$

The MOORA method is also a newly proposed MCDM method. Although the MOORA is a newly proposed method, it is applied to solve many economic, managerial and construction problems, and is presented in a significant number of papers published in journals, such as: Brauers and Zavadskas (2006, 2009), Brauers et al. (2008), Kalibatas and Turskis (2008), Brauers and Ginevicius (2009), Ginevicius et al. (2010a), Chakraborty (2011).

Brauers and Zavadskas (2010a) also presented MULTIMOORA method, as an extension of MOORA method with full multiplicative form. As MOORA method, 
MULTIMOORA method is also widely used for solving numerous problems. From many papers few are mentioned here: Brauers and Zavadskas (2010a, 2010b, 2011), Brauers and Ginevicius (2010), Balezentis et al. (2010), Kracka et al. (2010), Balezentis, A. and Balezentis, T. (2011).

Similar to other MCDM methods, for MOORA and MULTIMOORA some extensions have been proposed. Brauers et al. (2011) proposed first fuzzy extension of the MOORA method, or more precisely MULTIMOORA method. Balezentis et al. (2012) further modified fuzzy MULTIMOORA, and proposed a fuzzy extension named MULTIMOORA-FG, which includes the use of linguistic variables and group decision making.

Besides these, there are other extensions, such as: Karande and Chakraborty (2012), and Dey et al. (2012) proposed fuzzy extensions of Ratio system approach of the MOORA method. Stanujkic et al. (2012a, $2012 b$ ) proposed a grey extension of the MOORA method.

Actuality of MOORA method also confirms a significant number of papers which have been published in numerous journals. In addition to the previously mentioned papers, below are given some new and significant, such as: Brauers and Zavadskas (2012), Chakraborty and Karande (2012), Archana and Sujatha (2012).

\section{5. (CP) Compromise Programming}

2.5. Compromise programming $(\mathrm{CP})$ is based on Minkowski $L_{p}$ metric. In $\mathrm{CP}$ the best alternative should have the shortest distance from the reference point (i.e. ideal solution), and its aggregation procedure can be shown by the following formula: $\min L_{p, i}=\left\{\sum_{j=1}^{n} w_{j}^{p}\left(\frac{x_{j}^{*}-x_{i j}}{x_{j}^{*}-x_{j}^{-}}\right)^{p}\right\}^{\frac{1}{p}}$,

where $L_{p, i}$ is distance metric of $i$-th alternative for a given parameter $p, x_{j}^{*}$ and $x_{i}^{-}$ are the most preferable and the worst performance rating of $j$-th criterion, and $p$ is metric, $p \in[1, \infty)$.

The parameter $p$, in formula (25) is used to represent the importance of the maximal deviation from the reference point. By varying the parameter $p$ from 1 to infinity, it is possible to move from minimizing sums of individual deviations to minimizing the maximal deviation to the ideal point.

The most preferable $x_{j}^{*}$ and the worst $x_{i}^{-}$ performance rating of $\mathrm{j}$-th criterion are determined using the following formulae:

$$
\begin{aligned}
& x_{j}^{*}=\left\{\begin{array}{ll}
\max _{i} x_{i j} ; & j \in \Omega_{\max } \\
\min _{i} x_{i j} ; & j \in \Omega_{\min }
\end{array},\right. \\
& x_{j}^{-}=\left\{\begin{array}{ll}
\min _{i} x_{i j} ; & j \in \Omega_{\max } \\
\max _{i} x_{i j} ; & j \in \Omega_{\min }
\end{array} .\right.
\end{aligned}
$$

The alternatives are ranked on the basis of their $L_{p, i}$ in descending order, and the alternative with the lowest value of $L_{p, i}$ is the best ranked. The best ranked alternative, based on the CP method, $A^{*}{ }_{C P}$ can be determined using the following formula:

$$
A_{C P}^{*}=\left\{A_{i}=\min _{i} L_{p, i}\right\} \text {. }
$$

Unlike the previously described MCDM methods, the aggregation procedure used in $\mathrm{CP}$ method also performs normalization of ratings, and because of that the normalization procedure does not have to be performed.

In the past, the Compromise 
programming methodology has made a prominent use in the field of water resources management, but it is also applied in many other fields, such as forest management and economy. Some of the more important studies that are based on the use of Compromise programming can be specified in the following: Wu and Chang (2004), Bender and Simonovic (2000), Poff et al. (2010), Andre et al. (2007), Tecle et al. (1998), Simonovic et al. (1992), Simonovic and Burn (1989), Duckstein and Opricovic (1980).

Compared with other MCDM methods, Compromise programming is significantly less used.

Similar to other MCDM methods, some extensions of Compromise programming are proposed, such as: Prodanovic and Simonovic (2003), Bilbao-Terol et al. (2006).

\section{6. (GRA) Grey Relational Analysis}

Grey relational analysis (GRA) was proposed as part of Grey system theory. Similar to the TOPSIS method, GRA is based on the use of the distance from an ideal solution. In the literature, many authors have discussed the use of different variants of the GRA, from which we, in this paper, present one simple and efficient which can be used when ratings are expressed with the crisp numbers.

In GRA, the most appropriate alternative is determined on the basis of Grey relational grade, which can be calculated using the following formula:

$G_{i}=\frac{1}{n} \sum_{j=1}^{n} w_{j} \xi_{i j}$,

where $\xi_{i j}$ is the grey relational coefficient of $i$-th alternative to the $j$-th criterion.
The grey relational coefficient of each alternative can be calculated using the following formula:

$$
\xi_{i j}=\frac{\min _{i} \min _{j}\left|r_{j}^{*}-r_{i j}\right|+\varsigma \max _{i} \max _{j}\left|r_{j}^{*}-r_{i j}\right|}{\left|r_{j}^{*}-r_{i j}\right|+\varsigma \max _{i} \max _{j}\left|r_{j}^{*}-r_{i j}\right|},
$$

where $r_{j}^{*}$ is most preferable normalized performance rating of $i$-th alternative according to $j$-th criterion, $\zeta$ is the distinguish coefficient, and $\varsigma \in[0,1]$.

The coordinates of the ideal point, i.e., the most preferable normalized ratings in relation to the criteria, can be determined using the following formula:

$$
\begin{aligned}
& A^{*}=\left\{r_{1}^{*}, r_{2}^{*}, \ldots, r_{n}^{*}\right\}= \\
& \left.=\left\{\max _{i} / j \in \Omega_{\max }\right),\left(\operatorname{minr}_{i} / j \in \Omega_{\min }\right)\right\},
\end{aligned}
$$

where $A^{*}$ is ideal point, also known as ideal solution, $r_{j}^{*}$ is $j$-th coordinate of ideal point, $r_{i j}$ is normalized performance rating of $i$-th alternative to the $j$-th criterion, and $\Omega_{\max }$ and $\Omega_{\text {min }}$ are sets of benefit and cost criteria, respectively.

Different authors use GRA with various normalization procedures, with or without transformation of cost type to benefit type criteria. In this paper, the use of GRA without transformation of cost type to benefit type criteria was discussed. Therefore, the normalized performance ratings can be calculated by using one of the following formulae:

$r_{i j}=\frac{x_{i j}}{x^{+}}$,

$r_{i j}=\frac{x_{i j}-x_{j}^{-}}{x_{j}^{+}-x_{j}^{-}}$, 
or the formulae (19) and (24).

After determining overall ranking index for each alternative, in GRA approach the alternative with smallest overall ranking index has higher priority (rank) and the most acceptable alternative can be determined by the following formula:

$A_{G R A}^{*}=\left\{A_{i}=\min _{i} G_{i}\right\}$.

Beside the above presented GRA approach, in the literature also are proposed some complex variant of GRA which are based on the well-known concept used in TOPSIS method, i.e., TOPSIS based GRA approach. Due to a clearer presentation, in this paper TOPSIS based GRA approach is marked as GRA(T) approach.

In the GRA(T) approach, the best ranked alternative can be determined using the following formula:

$G_{i}=\frac{g_{i}^{*}}{g_{i}^{-}}$,

where:

$g_{i}^{*}=\sum_{j=1}^{n} w_{j} \xi_{i j}^{*}$,

$\xi_{i j}^{*}=\frac{\min _{i} \min _{j}\left|r_{j}^{*}-r_{i j}\right|+\varsigma \max _{i} \max _{j}\left|r_{j}^{*}-r_{i j}\right|}{\left|r_{j}^{*}-r_{i j}\right|+\varsigma \max _{i} \max _{j}\left|r_{j}^{*}-r_{i j}\right|}$,

and,

$g_{i}^{-}=\sum_{j=1}^{n} w_{j} \xi_{i j}^{-}$,

$\xi_{i j}^{-}=\frac{\min _{i} \min _{j}\left|r_{j}^{-}-r_{i j}\right|+\varsigma \max _{i} \max _{j}\left|r_{j}^{-}-r_{i j}\right|}{\left|r_{j}^{-}-r_{i j}\right|+\varsigma \max _{i} \max _{j}\left|r_{j}^{-}-r_{i j}\right|}$.

As it can be concluded from the above, selection of the best placed alternative using TOPSIS based GRA approach is based on the ratio between distance of an alternative from the ideal and non-ideal solution.

Therefore, in TOPSIS based GRA approach, there are two characteristic points in $n$-dimensional space, i.e. ideal and antiideal point, also known as ideal and antiideal solution.

The ideal point is determined as already shown in formula (31). The anti-ideal point is determined as follows:

$$
\begin{aligned}
& A^{-}=\left\{r_{1}^{-}, r_{2}^{-}, \ldots, r_{n}^{-}\right\}= \\
& \left.=\left\{\min _{i} r_{i j} / j \in \Omega_{\max }\right),\left(\max _{i} r_{i j} / j \in \Omega_{\min }\right)\right\},
\end{aligned}
$$

where $A^{-}$is anti-ideal point, $r_{i j}^{-}$is $j$-th coordinate of anti-ideal point.

GRA approach is used to solve many decision-making problems. The achieved results, and the usability of the GRA approach, are presented in a number of papers published in many significant journals. From many papers, some most prominent are mentioned here: Chan and Tong (2007), Tosun (2006), Fung (2003), Lin et al. (2002), Fu et al. (2001).

\subsection{VIKOR method}

The development of the VIKOR method, similar to $\mathrm{CP}$ method, also started from the Minkowski $L_{p}$ metric, already shown by formula (25). The VIKOR method uses two characteristic metrics to formulate ranking measure, $p=1$ and $p \rightarrow \infty$, for which the formula (25) gets the following specific forms:

$$
\begin{aligned}
& S_{i}=\sum_{j=1}^{n} w_{j}\left(x_{j}^{*}-x_{i j}\right) /\left(x_{j}^{*}-x_{j}^{-}\right) ; \text {for } p=1, \text { and } \\
& R_{i}=\max _{j}\left[w_{j}\left(x_{j}^{*}-x_{i j}\right) /\left(x_{j}^{*}-x_{j}^{-}\right)\right] ; \text {for } p \rightarrow \infty,
\end{aligned}
$$


where $S_{j}$ and $R_{j}$ as the average and the worst group score of $i$-th alternative.

The VIKOR method is based on idea of ideal and compromise solution, and the overall ranking index for each alternative is calculated using the following formula:

$$
Q_{i}=v \frac{\left(S_{i}-S^{*}\right)}{\left(S^{-}-S^{*}\right)}+(1-v) \frac{\left(R_{i}-R^{*}\right)}{\left(R^{-}-R^{*}\right)}
$$

where:

$$
\begin{aligned}
& S^{*}=\min _{i} S_{i}, \\
& S^{-}=\max _{i} S_{i}, \\
& R^{*}=\min _{i} R_{i}, \\
& R^{-}=\max _{i} R_{i},
\end{aligned}
$$

and $v$ is significance of the strategy of criteria (objectives) majority which value is usually set to be 0.5 .

Compared to other previously considered MCDM methods, determination of the most appropriate alternative using VIKOR method is more complex, and it can be described as follows: The alternatives are sorted by values $S, R$ and $Q$ in the ascending order. The most acceptable alternative $A^{\prime}$ is the one with the minimum value of $Q$, if two complementary conditions are satisfied (Opricovic \& Tzeng 2004):

C1. Acceptable advantage: The condition $C 1$ is satisfied if the following equation is satisfied:

$Q\left(A^{\prime \prime}\right)-Q\left(A^{\prime}\right) \geq D Q$

where:

$D Q=1 /(m-1)$, and
$A^{\prime \prime}$ is the alternative having the second position in the ranking list by $Q$, and $\mathrm{m}$ is the number of alternatives.

\section{C2. Acceptable stability in decision}

making: Alternative $A^{\prime}$ must also be the best ranked by $S$ and/or $R$.

If one of these conditions is not satisfied, then, a set of compromise solutions with the advantage rate is proposed instead of most acceptable alternative (Antucheviciene et al. 2011). This set will consist of:

- the alternatives $A^{\prime}$ and $A^{\prime \prime}$; if only condition $C 2$ is not satisfied, or

- the alternatives $A^{\prime}, A^{\prime \prime}, \ldots, A^{n}$; if conditions $\boldsymbol{C} 1$ and $C 2$ are not satisfied, where $A^{n}$ is determined by the relation:

$$
Q\left(A^{n}\right)-Q\left(A^{\prime}\right) \leq D Q .
$$

The VIKOR method has been used for solving numerous MCDM problems. In order to solve complex decision-making problems Opricovic (2007) proposed a fuzzy extension of VIKOR method, named VIKOR-F. Sayadi et al. (2009) also proposed a grey extension of VIKOR method.

Numbers of papers have been published where VIKOR or VIKOR-F was applied. As more significant, the following works can be mentioned: Tong et al. (2007), Rao (2008), Chen and Wang (2009), Yu-Ping et al. (2009), Kaya and Kahraman (2010).

The important characteristic of this method is that the number of papers published in the last two years has increased significantly compared to the previous period. From many papers few are mentioned here: Opricovic, S. (2011), Jahan et al. (2011), San Cristobal (2011), Roostaee et al. (2012), Chiu et al. (2012), Liu et al. (2012). 


\subsection{TOPSIS method}

The TOPSIS method is one of the most widely used MCDM methods. The basic principle of TOPSIS method is that the best alternative should have the shortest distance from the ideal solution and the farthest distance from the anti-ideal solution. A relative distance of each alternative from ideal and anti-ideal solution is obtained as:

$C_{i}=\frac{d_{i}^{-}}{d_{i}^{+}+d_{i}^{-}}$,

where $d_{i}^{+}$and $d_{i}^{-}$are separation measures of alternative $i$ from the ideal and anti-ideal solution, respectively; $C_{i}$ is relative distance of alternative $\mathrm{i}$ to the ideal solution, and $C_{i} \in[0,1]$.

The largest value of the criterion $C_{i}$ correlates with the best alternative. Therefore, in TOPSIS method, the alternatives are ranked on the basis of their $C_{i}$ in ascending order, and the alternative with the highest value of $C_{i}$ is the best ranked. The best ranked, or the most preferable, alternative $A_{T P S}^{*}$ can be determined using the following formula:

$A_{T P S}^{*}=\left\{A_{i}=\max _{i} C_{i}\right\}$.

The separation measures of each alternative, from the ideal and anti-ideal solution, are computed using following formulae:

$$
\begin{aligned}
& d_{i}^{+}=\left\{\sum_{j=1}^{n}\left[w_{j}\left(r_{i j}-r_{i}^{+}\right)\right]^{2}\right\}^{1 / 2}, \text { and } \\
& d_{i}^{-}=\left\{\sum_{j=1}^{n}\left[w_{j}\left(r_{i j}-r_{i}^{-}\right)\right]^{2}\right\}^{1 / 2} .
\end{aligned}
$$

The ideal $A^{*}$ and the anti-ideal $A^{-}$solution in TOPSIS method can be determined using the already mentioned formulae (31) and (40), respectively.

It can be seen from the formulae (53) and (54) that ordinary TOPSIS method is based on the Euclidean distance. In addition to Euclidean distance, in the literature are also presented some examples where TOPSIS method was used with other metrics, especially with a city-block distance (Chang et al., 2010; Shanian \& Savadogo, 2006; Yoon \& Hwang, 1980).

TOPSIS method, as well as the MOORA method, uses Vector normalization procedure, already given by formula (24). However, in the literature is also discussed the use of TOPSIS method with other normalization procedures, especially when its fuzzy extensions are proposed, such as in Saremi et al. (2009), Yang and Hung (2007), Wang and Elhag (2006), and so on.

TOPSIS is one of the most actual MCDM methods, which is confirmed by a number of papers published in scientific journals in 2012. From a very large number, just a few are mentioned here, such as: Tansel (2012), Ravi (2012), Huang and Peng (2012), Buyukuzkan (2012), Arslan and Cunkas (2012).

In the past, TOPSIS method was used rather frequently. This is also confirmed by a number of papers, such as: Boran et al. (2009), Dagdeviren et al. (2009), Ertugrul and Karakasoglu (2009), Wang and Chang (2007).

Similar to other MCDM methods, a number of extensions have been proposed for TOPSIS method, such as: Dagdeviren et al. (2009), Ashtiani et al. (2009), Shih et al. (2007), Wang and Elhag (2006), Jahanshahloo et al. (2006), Chen (2000). 


\section{A CASE STUDY AND DISCUSSION OF RESULTS}

In this section we consider a case study of ranking some Serbian commercial banks. In order to perform more objective conclusions in terms of the applicability of MCDM methods, the influence which the weights of criteria, the used approaches and the applied normalization procedure have on the selection of the most appropriate alternative and obtained ranking orders of alternatives, is also taken into consideration in this section.

\subsection{A Case Study: The Case of ranking Serbian banks}

In the literature, many papers have been devoted to the ranking of banks, as well as to determining banks' performances. Among many, here are mentioned only a few, such as: Ferreira et al. (2012), Stankeviciene and Mencaite (2012), Brauers et al. (2012), Cehulic et al. (2011), Ginevicius and
Podviezko (2011), Ginevicius et al. (2010c), Cetin and Cetin (2010), Wu et al. (2009), Rakocevic and Dragasevic (2009), Ginevicius and Podvezko (2008), Hunjak and Jakocevic (2001), Yeh (1996), Sherman and Gold (1985).

This case study presents the ranking results of five commercial banks in Serbia, based on objective criteria. These criteria and their sub-criteria, adopted from Yeh (1996) and Hunjak and Jakocevic (2001), are shown in Table 1.

Weights of criteria, sub-criteria and the resulting weights, obtained on the basis of pairwise comparisons, are shown in Table 2. Due to limited space, the calculation procedure is omitted.

Ratings, i.e. performance ratings, of the considered banks, in relation to selected evaluation criteria, are shown in Table 3 . These ratings are calculated based on data available on the web sites of the considered banks, i.e. financial reports for 2011 year, and data available on the website of the National Bank of Serbia.

Table 1. Quantitative criteria for bank performance determination

\begin{tabular}{|l|c|l|}
\hline Criteria & Sub-criteria & Definitions \\
\hline \multirow{4}{*}{ Liquidity $(L)$} & $L_{1}$ & $\begin{array}{l}\text { Cash and cash equivalent + cash due from } \\
\text { financial institutions / total deposits }\end{array}$ \\
\cline { 2 - 3 } & $L_{2}$ & Total loans / total deposits \\
\cline { 2 - 3 } & $L_{3}$ & $\begin{array}{l}\text { Net cash flow from operating activities / } \\
\text { total cash flow }\end{array}$ \\
\hline \multirow{4}{*}{ Efficiency $(E)$} & $E_{1}$ & Operating cost / operating income \\
\cline { 2 - 3 } & $E_{2}$ & Provisions for loans / net interest income \\
\cline { 2 - 3 } & $E_{3}$ & $\begin{array}{l}\text { Operating income / total number of } \\
\text { employees }\end{array}$ \\
\hline \multirow{4}{*}{ Capital adequacy $(C)$} & $P_{1}$ & Profit before taxes / equity \\
\hline & $P_{2}$ & Profit before taxes / asset \\
\cline { 2 - 3 } & $P_{3}$ & Profit before taxes / operating income \\
\hline & $C_{1}$ & Total liabilities / equity \\
\hline & $C_{2}$ & Equity / loans \\
\cline { 2 - 3 } & $C_{3}$ & Total deposits / equity \\
\hline$C_{4}$ & Capital adequacy ratio \\
\hline
\end{tabular}


Table 2. Relative weights of evaluation criteria

\begin{tabular}{|l|c|l|c|c|}
\hline Criteria & $w_{c}$ & Sub-criteria & $w_{s c}$ & $w_{j}$ \\
\hline \multirow{4}{*}{ Liquidity $(L)$} & \multirow{3}{*}{0.375} & $L_{1}$ & 0.429 & 0.161 \\
\cline { 3 - 5 } & & $L_{2}$ & 0.143 & 0.054 \\
\cline { 3 - 5 } & $L_{3}$ & 0.429 & 0.161 \\
\hline \multirow{4}{*}{ Efficiency $(E)$} & \multirow{3}{*}{0.125} & $E_{1}$ & 0.637 & 0.080 \\
\cline { 3 - 5 } & & $E_{2}$ & 0.258 & 0.032 \\
\cline { 3 - 5 } & $E_{3}$ & 0.105 & 0.013 \\
\hline \multirow{4}{*}{ Profitability $(P)$} & $P_{1}$ & 0.309 & 0.039 \\
\hline \multirow{4}{*}{ Capital adequacy $(C)$} & \multirow{3}{*}{0.125} & $P_{2}$ & 0.582 & 0.073 \\
\hline & & $P_{3}$ & 0.109 & 0.014 \\
\hline & & $C_{1}$ & 0.217 & 0.081 \\
\hline & $C_{2}$ & 0.125 & 0.047 \\
\cline { 3 - 5 } & $C_{3}$ & 0.165 & 0.062 \\
\hline & $C_{4}$ & 0.494 & 0.185 \\
\hline
\end{tabular}

different alternatives as the best ranked. It might be a little confusing.

The obtained rankings orders, shown in the column VII of Table 4, also look confusing. By applying the same MCDM method and various normalization procedures, different ranking orders are obtained.

In order to resolve doubts about the best ranked alternative, ranking of banks was again performed using various MCDM methods. Obtained ranking results are shown in Table 5.

Due to easier comparison, in Table 5 are repeated results obtained by the SAW

Table 3. Initial decision matrix - banks' performances and criteria weights

\begin{tabular}{|c|c|c|c|c|c|c|c|c|}
\hline \multirow{2}{*}{\multicolumn{2}{|c|}{ Criteria and sub-criteria }} & \multirow{3}{*}{$\begin{array}{c}w_{i} \\
0.161 \\
\end{array}$} & \multirow{3}{*}{$\begin{array}{l}\text { Opt. } \\
\max \\
\end{array}$} & \multicolumn{5}{|c|}{ Alternatives (Banks) } \\
\hline & & & & \multirow{2}{*}{$\begin{array}{c}B_{1} \\
2.50\end{array}$} & \multirow{2}{*}{$\begin{array}{c}B_{2} \\
1.47 \\
\end{array}$} & \multirow{2}{*}{$\begin{array}{c}B_{3} \\
1.31 \\
\end{array}$} & \multirow{2}{*}{$\begin{array}{c}B_{4} \\
1.34 \\
\end{array}$} & \multirow{2}{*}{\begin{tabular}{|c|}
$B_{5}$ \\
1.57 \\
\end{tabular}} \\
\hline \multirow{3}{*}{$L$} & $L_{1}$ & & & & & & & \\
\hline & $L_{2}$ & 0.054 & $\max$ & 0.76 & 1.02 & 1.36 & 1.06 & 1.50 \\
\hline & $L_{3}$ & 0.161 & $\max$ & 0.26 & 0.29 & 0.18 & 0.18 & 0.24 \\
\hline \multirow{3}{*}{ E } & $E_{1}$ & 0.080 & $\min$ & 0.49 & 0.28 & 0.43 & 0.43 & 0.44 \\
\hline & $E_{2}$ & 0.032 & $\min$ & 0.18 & 0.22 & 0.01 & 0.16 & 0.13 \\
\hline & $E_{3}$ & 0.013 & $\max$ & 5.01 & 6.51 & 12.65 & 24.58 & 12.19 \\
\hline \multirow{3}{*}{$P$} & $P_{1}$ & 0.039 & $\max$ & 0.012 & 0.016 & 0.026 & 0.043 & 0.002 \\
\hline & $P_{2}$ & 0.073 & $\max$ & 0.110 & 0.101 & 0.230 & 0.220 & 0.010 \\
\hline & $P_{3}$ & 0.014 & $\max$ & 0.179 & 0.225 & 0.338 & 0.527 & 0.038 \\
\hline \multirow{4}{*}{ C } & $C_{1}$ & 0.081 & $\min$ & 5.36 & 2.69 & 4.20 & 2.20 & 3.57 \\
\hline & $C_{2}$ & 0.047 & $\max$ & 0.26 & 0.48 & 0.28 & 0.45 & 0.34 \\
\hline & $C_{3}$ & 0.062 & $\min$ & 4.97 & 2.02 & 2.57 & 2.06 & 1.91 \\
\hline & $C_{4}$ & 0.185 & $\max$ & 18.70 & 29.00 & 17.10 & 32.00 & 25.90 \\
\hline
\end{tabular}

Note: Table 3 does not contain information on all banks which operate in Serbia. This table contains only performance ratings for some characteristic bank.

The ranking of banks was started using SAW method. The results of ranking banks obtained using SAW method and various normalization procedures are shown in Table 4.

Based on data from Table 4, it can be determined that SAW method, used with various normalization procedures, gave method used with Max and MaxMin normalization procedures.

From Tables 4 and 5 can be seen that there is a certain similarity in results obtained by using so-called performance-based methods, such as ARAS, COPRAS, MOORA(RS) and SAW method used with Max normalization procedure. 
Table 4. Ranking results obtained using SAW method and various normalization procedures

\begin{tabular}{|c|c|c|c|c|c|c|c|c|}
\hline \multirow{2}{*}{\begin{tabular}{|l|}
\multicolumn{1}{c}{ Banks } \\
Normalization \\
methods
\end{tabular}} & & $B_{1}$ & $B_{2}$ & $B_{3}$ & $B_{4}$ & $B_{5}$ & $\begin{array}{l}\text { Best } \\
\text { ranked }\end{array}$ & $\begin{array}{c}\text { Ranking } \\
\text { orders }^{1}\end{array}$ \\
\hline & & I & II & III & IV & V & VI & VII \\
\hline \multirow{2}{*}{ Max method } & $Q_{i}$ & 0.623 & 0.768 & 0.643 & 0.780 & 0.648 & \multirow{2}{*}{$B_{4}$} & \multirow{2}{*}{$B_{4} \succ B_{2} \succ B_{5}$} \\
\hline & Rank & 5 & 2 & 4 & 1 & 3 & & \\
\hline \multirow{2}{*}{ Sum method } & $Q_{i}$ & 0.328 & 0.369 & 0.345 & 0.384 & 0.338 & \multirow{2}{*}{$B_{4}$} & \multirow{2}{*}{$B_{4} \succ B_{2} \succ B_{3}$} \\
\hline & Rank & 5 & 2 & 3 & 1 & 4 & & \\
\hline \multirow{2}{*}{$\begin{array}{l}\text { Vector } \\
\text { normalization }\end{array}$} & $Q_{i}$ & 0.413 & 0.500 & 0.442 & 0.524 & 0.438 & \multirow{2}{*}{$B_{4}$} & \multirow{2}{*}{$B_{4} \succ B_{2} \succ B_{3}$} \\
\hline & Rank & 5 & 2 & 3 & 1 & 4 & & \\
\hline \multirow{2}{*}{$\begin{array}{l}\text { Max-Min } \\
\text { method }\end{array}$} & $Q_{i}$ & 0.350 & 0.653 & 0.290 & 0.558 & 0.448 & \multirow{2}{*}{$B_{2}$} & \multirow{2}{*}{$B_{2} \succ B_{4} \succ B_{5}$} \\
\hline & Rank & 4 & 1 & 5 & 2 & 3 & & \\
\hline
\end{tabular}

${ }^{1}$ Ranking orders of three best ranked alternatives

Table 5. Ranking results obtained using various MCDM methods

\begin{tabular}{|c|c|c|c|c|c|c|c|c|}
\hline Banks & & $B_{1}$ & $B_{2}$ & $B_{3}$ & $B_{4}$ & $B_{5}$ & $\begin{array}{c}\text { Best } \\
\text { ranke } \\
\mathrm{d}\end{array}$ & $\begin{array}{c}\text { Ranking } \\
\text { orders }\end{array}$ \\
\hline Methods & & I & II & III & IV & V & VI & VII \\
\hline \multirow{2}{*}{$\begin{array}{l}\text { SAW } \\
\text { (Max) }\end{array}$} & $Q_{i}$ & 0.623 & 0.768 & 0.643 & 0.780 & 0.648 & \multirow{2}{*}{$B_{4}$} & \multirow[t]{2}{*}{$B_{4} \succ B_{2} \succ B_{5}$} \\
\hline & Rank & 5 & 2 & 4 & 1 & 3 & & \\
\hline \multirow{2}{*}{ ARAS } & $Q_{i}$ & 0.728 & 0.895 & 0.856 & 0.937 & 0.747 & \multirow{2}{*}{$B_{4}$} & \multirow[t]{2}{*}{$B_{4} \succ B_{2} \succ B_{3}$} \\
\hline & Rank & 5 & 2 & 3 & 1 & 4 & & \\
\hline \multirow{2}{*}{ COPRAS } & $Q_{i}$ & 0.181 & 0.215 & 0.190 & 0.230 & 0.183 & \multirow{2}{*}{$B_{4}$} & \multirow{2}{*}{$B_{4} \succ B_{2} \succ B_{3}$} \\
\hline & Rank & 5 & 2 & 3 & 1 & 4 & & \\
\hline \multirow{2}{*}{$\begin{array}{l}\text { MOORA } \\
\text { (RS) }\end{array}$} & $Q_{i}$ & 0.158 & 0.245 & 0.187 & 0.269 & 0.183 & \multirow{2}{*}{$B_{4}$} & \multirow{2}{*}{$B_{4} \succ B_{2} \succ B_{3}$} \\
\hline & Rank & 5 & 2 & 3 & 1 & 4 & & \\
\hline \multirow{2}{*}{$\begin{array}{c}\mathrm{CP} \\
(p=1)\end{array}$} & $L_{i}, 1$ & 0.650 & 0.347 & 0.710 & 0.442 & 0.552 & \multirow{2}{*}{$B_{2}$} & \multirow[t]{2}{*}{$B_{2} \succ B_{4} \succ B_{5}$} \\
\hline & Rank & 4 & 1 & 5 & 2 & 3 & & \\
\hline \multirow{2}{*}{$\begin{array}{c}\text { GRA } \\
\text { (MaxMin) }\end{array}$} & $G_{i}$ & 0.704 & 0.491 & 0.755 & 0.589 & 0.581 & \multirow{2}{*}{$B_{2}$} & \multirow{2}{*}{$B_{2} \succ B_{5} \succ B_{4}$} \\
\hline & Rank & 4 & 1 & 5 & 3 & 2 & & \\
\hline \multirow{2}{*}{$\begin{array}{c}\text { MOORA } \\
\text { (RP) }\end{array}$} & & 0.045 & 0.044 & 0.050 & 0.049 & 0.046 & \multirow{2}{*}{$B_{2}$} & \multirow[t]{2}{*}{$B_{2} \succ B_{1} \succ B_{5}$} \\
\hline & Rank & 2 & 1 & 5 & 4 & 3 & & \\
\hline \multirow{2}{*}{$\begin{array}{c}\mathrm{CP} \\
(p=2)\end{array}$} & $L_{i, 2}$ & 0.233 & 0.161 & 0.307 & 0.235 & 0.200 & \multirow{2}{*}{$B_{2}$} & \multirow[t]{2}{*}{$B_{2} \succ B_{5} \succ B_{1}$} \\
\hline & Rank & 3 & 1 & 5 & 4 & 2 & & \\
\hline \multirow{2}{*}{$\begin{array}{c}\text { GRA } \\
\text { (T) }\end{array}$} & $G_{i}$ & 0.882 & 1.080 & 0.870 & 1.163 & 1.026 & \multirow{2}{*}{$B_{3}$} & \multirow{2}{*}{$B_{3} \succ B_{1} \succ B_{5}$} \\
\hline & Rank & 2 & 4 & 1 & 5 & 3 & & \\
\hline \multirow{2}{*}{ VIKOR } & $Q_{i}$ & 0.750 & 0.113 & 1.000 & 0.426 & 0.282 & \multirow{2}{*}{$B_{2}, B_{5}$} & \multirow[t]{2}{*}{$B_{2} \succ B_{5} \succ B_{4}$} \\
\hline & Rank & 4 & 1 & 5 & 3 & 2 & & \\
\hline \multirow{2}{*}{ TOPSIS } & $C_{i}$ & 0.441 & 0.541 & 0.418 & 0.573 & 0.409 & \multirow{2}{*}{$B_{4}$} & $B_{4} \succ B_{2} \succ B_{1}$ \\
\hline & Rank & 3 & 2 & 4 & 1 & 5 & & \\
\hline SAW & & 0.350 & 0.653 & 0.290 & 0.558 & 0.448 & $R$ & $B_{2} \succ B_{4} \succ B_{5}$ \\
\hline (MaxMin) & Rank & 4 & 1 & 5 & 2 & 3 & $B_{2}$ & \\
\hline
\end{tabular}

A deviation from the identified is more noticeable, and obtained results are similarities in achieved results can be seen in the same as when the SAW method with the case of using GRA approach. In addition, MaxMin normalization procedure is used. in case of using $\mathrm{CP}$, and $p=1$, the deviation $\quad$ As is stated in subsections 2.5 and 2.6, the 
GRA and CP methods are based on the idea that the best placed alternative has the smallest distance from the ideal point (solution) and therefore they can be placed in so-called distance-based approach methods.

If more detailed consider the MaxMin normalization procedure, which is shown by formula (7), we can notice that its use transforms SAW method into so-called distance-based approach methods, instead of the usual performance-based approach which is obtained using Max, Sum or Vector normalization procedures. Therefore, a weak correlation observed in the results obtained by the above mentioned method is quite expected.

The results obtained by using VIKOR also confirm above mentioned conclusions. However, in the case when VIKOR method is used, the second condition required in order to select the most acceptable alternative, $\boldsymbol{C} 1$, is not satisfied, and therefore the set of compromise solutions is obtained, i.e. the set which contains alternatives $B_{2}$ and $B_{5}$.

From Table 5 can also be concluded that most of the distance-based methods stand $B_{2}$ as the most acceptable alternative. However, this is not so in the case of TOPSIS method application, one of most prominent methods. When applying TOPSIS method, the highest ranked alternative is $B_{4}$.

Data from columns VI and VII of Table 4 and Table 5 indicate that alternatives $B_{4}$ and $B_{2}$ are real candidates for the most acceptable alternative. However, on the basis of these data the most appropriate alternative cannot be determined for certain.

It is known that the criteria weights in MCDM models have significant influence on the selection of the most acceptable alternatives. It is also known that the used normalization procedures, as well as the aggregation procedure, have significant influence on selection of the best placed alternative.

Slightly confusing results obtained when using different MCDM methods in some way indicate that this is a characteristic case where mutual influence of the relative weights of criteria, applied normalization methods and aggregation procedures is particularly emphasized.

In order to make more realistic conclusions, below are considered influence of the criteria weights and impact of normalization procedures upon ranking order of considered alternatives.

\subsection{Comparative Analysis: Examining the impact of criteria weights on ranking order}

In order to make more objective conclusions, in this section we reconsider the previous example of ranking banks, but with modified weights of criteria.

In the first case (Case I), all criteria have the same weight, and the resulting weights of sub-criteria are calculated using the following formula:

$$
w_{j}=\frac{1}{n_{s c}} w_{c},
$$

where $w_{j}$ is resulting weight of $j$-th criterion, $n_{s c}$ is the number of sub-criteria of $c$-th criterion, and $w_{c}$ is weight of $c$-th criterion.

As shown in Table 6, criteria Liquidity, Efficiency and Profitability and Capital adequacy have the same weight, and it is 0.25 . Criteria Liquidity, Efficiency and Profitability have three sub-criteria, and therefore they have the same weight, which 
Table 6. Relative weights of evaluation criteria

\begin{tabular}{|c|c|c|c|}
\hline Criteria & $\begin{array}{c}\text { Weights of criteria } \\
w_{c}\end{array}$ & Sub-criteria & $\begin{array}{c}\text { Resulting weights } \\
\text { of sub-criteria } \\
w_{j}\end{array}$ \\
\hline \multirow{3}{*}{ Liquidity $(L)$} & \multirow{3}{*}{0.25} & $L_{1}$ & 0.083 \\
\hline & & $L_{2}$ & 0.083 \\
\hline & & $L_{3}$ & 0.083 \\
\hline \multirow{3}{*}{ Efficiency $(E)$} & \multirow{3}{*}{0.25} & $E_{1}$ & 0.083 \\
\hline & & $E_{2}$ & 0.083 \\
\hline & & $E_{3}$ & 0.083 \\
\hline \multirow{3}{*}{ Profitability $(P)$} & \multirow{3}{*}{0.25} & $P_{1}$ & 0.083 \\
\hline & & $P_{2}$ & 0.083 \\
\hline & & $P_{3}$ & 0.083 \\
\hline \multirow{4}{*}{ Capital adequacy $(C)$} & \multirow{4}{*}{0.25} & $C_{1}$ & 0.063 \\
\hline & & $C_{2}$ & 0.063 \\
\hline & & $C_{3}$ & 0.063 \\
\hline & & $C_{4}$ & 0.063 \\
\hline
\end{tabular}

is 0.083 . Criterion Capital adequacy has four sub-criteria have value 0.077 , as shown in sub-criteria, which is why their weight is Table 7.

0.063 .

In the second case (Case II), we start from demand that the resulting weights of all subcriteria are the same, and also the following condition is satisfied:

$\sum_{j=1}^{n} w_{j}=1$.

Comparative review of the best ranked alternatives, as well as ranking orders achieved in the case study, and scenarios I and II are shown in the Table 8.

From Table 8 can be concluded that changes in criteria weights may have impact on ranking order of alternatives, as shown in columns I and II, but it is not a strong rule, as

Therefore, the resulting weights of all shown in columns II and III.

Table 7. Relative weights of evaluation criteria

\begin{tabular}{|l|c|c|}
\hline \multirow{3}{*}{ Criteria } & Sub-criteria & $\begin{array}{c}\text { Resulting weights of } \\
\text { sub-criteria } \\
w_{j}\end{array}$ \\
\hline \multirow{3}{*}{ Liquidity $(L)$} & $L_{1}$ & 0.077 \\
\hline & $L_{2}$ & 0.077 \\
\cline { 2 - 3 } & $L_{3}$ & 0.077 \\
\hline \multirow{3}{*}{ Efficiency $(E)$} & $E_{1}$ & 0.077 \\
\cline { 2 - 3 } & $E_{2}$ & 0.077 \\
\cline { 2 - 3 } & $E_{3}$ & 0.077 \\
\hline \multirow{3}{*}{ Profitability $(P)$} & $P_{1}$ & 0.077 \\
\hline & $P_{2}$ & 0.077 \\
\cline { 2 - 3 } & $P_{3}$ & 0.077 \\
\hline \multirow{3}{*}{ Capital adequacy $(C)$} & $C_{1}$ & 0.077 \\
\cline { 2 - 3 } & $C_{2}$ & 0.077 \\
\cline { 2 - 3 } & $C_{3}$ & 0.077 \\
\cline { 2 - 3 } & $C_{4}$ & 0.077 \\
\hline
\end{tabular}


Table 8. Comparative review of the ranking orders obtained using different weights

\begin{tabular}{|l|c|c|c|}
\hline \multicolumn{1}{|c|}{ Method } & Case study & Case I & Case II \\
\hline SAW (Max) & $B_{4} \succ B_{2} \succ B_{5}$ & $B_{4} \succ B_{3} \succ B_{2}$ & $B_{4} \succ B_{3} \succ B_{2}$ \\
\hline SAW (Sum) & $B_{4} \succ B_{2} \succ B_{3}$ & $B_{4} \succ B_{3} \succ B_{2}$ & $B_{4} \succ B_{3} \succ B_{2}$ \\
\hline SAW (VN) & $B_{4} \succ B_{2} \succ B_{3}$ & $B_{4} \succ B_{3} \succ B_{2}$ & $B_{4} \succ B_{3} \succ B_{2}$ \\
\hline SAW (MaxMin) & $B_{2} \succ B_{4} \succ B_{5}$ & $B_{4} \succ B_{2} \succ B_{3}$ & $B_{4} \succ B_{2} \succ B_{3}$ \\
\hline ARAS & $B_{4} \succ B_{2} \succ B_{3}$ & $B_{3} \succ B_{4} \succ B_{2}$ & $B_{3} \succ B_{4} \succ B_{2}$ \\
\hline COPRAS & $B_{4} \succ B_{2} \succ B_{3}$ & $B_{4} \succ B_{3} \succ B_{2}$ & $B_{4} \succ B_{3} \succ B_{2}$ \\
\hline MOORA (RS) & $B_{4} \succ B_{2} \succ B_{3}$ & $B_{4} \succ B_{3} \succ B_{2}$ & $B_{4} \succ B_{3} \succ B_{2}$ \\
\hline CP $(p=1)$ & $B_{2} \succ B_{4} \succ B_{5}$ & $B_{4} \succ B_{2} \succ B_{3}$ & $B_{4} \succ B_{2} \succ B_{3}$ \\
\hline GRA (MaxMin) & $B_{2} \succ B_{5} \succ B_{4}$ & $B_{5} \succ B_{3} \succ B_{2}$ & $B_{5} \succ B_{3} \succ B_{2}$ \\
\hline MOORA (RP) & $B_{2} \succ B_{1} \succ B_{5}$ & $B_{3} \succ B_{4} \succ B_{2}$ & $B_{3} \succ B_{4} \succ B_{2}$ \\
\hline CP $(p=2)$ & $B_{2} \succ B_{5} \succ B_{1}$ & $B_{4} \succ B_{2} \succ B_{3}$ & $B_{4} \succ B_{2} \succ B_{3}$ \\
\hline GRA (T) & $B_{3} \succ B_{1} \succ B_{5}$ & $B_{3} \succ B_{1} \succ B_{5}$ & $B_{3} \succ B_{1} \succ B_{5}$ \\
\hline VIKOR & $B_{2} \approx B_{5} \succ B_{4}$ & $B_{4} \approx B_{2} \succ B_{3}$ & $B_{4} \cong B_{2} \succ B_{3}$ \\
\hline TOPSIS & $B_{4} \succ B_{2} \succ B_{1}$ & $B_{4} \succ B_{3} \succ B_{2}$ & $B_{4} \succ B_{3} \succ B_{2}$ \\
\hline
\end{tabular}

\subsection{Comparative Analysis: Examining} the impact of distance metric and normalization procedure in TOPSIS method

As stated in section 2.8, when TOPSIS method is considered, ordinary TOPSIS method is based on the use of Vector normalization and Euclidean distance from the ideal and anti-ideal solution.

However, there are also some examples where TOPSIS method was used with other normalization procedures, especially in the case of fuzzy or grey extensions of TOPSIS method. In the literature the use of TOPSIS method was also considered with other metrics, such as city block distance.

In order to more accurately determine influence which normalization and aggregation procedures have, in this section are presented and discussed results of banks ranking which are obtained using some modified variants of TOPSIS method.
In column I of Table 9 are shown the results obtained by using ordinary TOPSIS method.

In column II of Table 9 are shown the results obtained by using a variant of TOPSIS method, where City block distance was used instead of Euclidean distance. In this case, replacement of distance metric has no impact on the best placed alternative, but it is reflecting on the ranking order of alternatives.

In columns III and IV, TOPSIS method was used with MaxMin normalization procedure. In column III are shown results when Euclidean distance was used, while in column IV when City block distance is used.

As can be seen from columns III and IV, the use of MaxMin normalization procedure had an impact on the best ranked alternative, i.e., alternative $B_{2}$ has become the best ranked alternative instead of alternative $B_{4}$. Unlike when vector normalization was used, the change of distance metrics had no 
Table 9. Ranking results obtained using different variants of TOPSIS method

\begin{tabular}{|c|c|c|c|c|c|c|c|c|}
\hline & \multicolumn{7}{|c|}{ Case Study } \\
\hline & \multicolumn{2}{|c|}{ I } & \multicolumn{2}{|c|}{ II } & \multicolumn{2}{c|}{ III } & \multicolumn{2}{c|}{ IV } \\
\hline Normalization & \multicolumn{2}{|c|}{ Vector } & \multicolumn{2}{|c|}{ Vector } & \multicolumn{2}{c|}{ MaxMin } & \multicolumn{2}{c|}{ MaxMin } \\
\hline Distance metric & \multicolumn{2}{|c|}{ Euclidean } & \multicolumn{2}{c|}{ City block } & \multicolumn{2}{c|}{ Euclidean } & \multicolumn{2}{c|}{ City block } \\
\hline Alternative & $C_{i}$ & Rank & $C_{i}$ & Rank & $C_{i}$ & Rank & $C_{i}$ & Rank \\
\hline$B_{1}$ & 0.441 & 3 & 0.328 & 5 & 0.465 & 4 & 0.350 & 4 \\
\hline$B_{2}$ & 0.541 & 2 & 0.577 & 2 & 0.616 & 1 & 0.653 & 1 \\
\hline$B_{3}$ & 0.418 & 4 & 0.410 & 3 & 0.268 & 5 & 0.290 & 5 \\
\hline$B_{4}$ & 0.573 & 1 & 0.646 & 1 & 0.497 & 2 & 0.558 & 2 \\
\hline$B_{5}$ & 0.409 & 5 & 0.399 & 4 & 0.466 & 3 & 0.448 & 3 \\
\hline Best placed & \multicolumn{2}{|c|}{$B_{4}$} & \multicolumn{2}{|c|}{$B_{4}$} & & $B_{2}$ & & $B_{2}$ \\
\hline Ranking order & \multicolumn{2}{|c|}{$B_{4} \succ B_{2} \succ B_{1}$} & \multicolumn{2}{|c|}{$B_{4} \succ B_{2} \succ B_{3}$} & \multicolumn{2}{c|}{$B_{2} \succ B_{4} \succ B_{5}$} & \multicolumn{2}{c|}{$B_{2} \succ B_{4} \succ B_{5}$} \\
\hline
\end{tabular}

influence upon ranking order of alternatives. caused significant changes on the best placed

Table 10 shows the results obtained using alternative, as well as ranking orders of different variants of TOPSIS method and alternatives.

weights from Table 7 (Case I).

Table 11 shows the results obtained using

Compared with the same columns of different variants of TOPSIS method and Table 9, the change of criteria weights have weights from Table 7 (Case II).

Table 10. Ranking results obtained using different variants of TOPSIS method

\begin{tabular}{|c|c|c|c|c|c|c|c|c|}
\hline & \multicolumn{8}{|c|}{ Case I } \\
\hline & \multicolumn{2}{|c|}{ I } & \multicolumn{2}{|c|}{ II } & \multicolumn{2}{|c|}{ III } & \multicolumn{2}{|c|}{ IV } \\
\hline Normalization & \multicolumn{2}{|c|}{ Vector } & \multicolumn{2}{|c|}{ Vector } & \multicolumn{2}{|c|}{ MaxMin } & \multicolumn{2}{|c|}{ MaxMin } \\
\hline Distance metric & \multicolumn{2}{|c|}{ Euclidean } & \multicolumn{2}{|c|}{ City block } & \multicolumn{2}{|c|}{ Euclidean } & \multicolumn{2}{|c|}{ City block } \\
\hline Alternatives & $C_{i}$ & Rank & $C_{i}$ & Rank & $C_{i}$ & Rank & $C_{i}$ & Rank \\
\hline$B_{1}$ & 0.291 & 5 & 0.237 & 5 & 0.340 & 5 & 0.249 & 5 \\
\hline$B_{2}$ & 0.387 & 3 & 0.436 & 3 & 0.506 & 2 & 0.534 & 2 \\
\hline$B_{3}$ & 0.599 & 2 & 0.565 & 2 & 0.486 & 3 & 0.468 & 3 \\
\hline$B_{4}$ & 0.704 & 1 & 0.750 & 1 & 0.579 & 1 & 0.651 & 1 \\
\hline$B_{5}$ & 0.312 & 4 & 0.317 & 4 & 0.412 & 4 & 0.391 & 4 \\
\hline Best placed & \multicolumn{2}{|c|}{$B_{4}$} & \multicolumn{2}{|c|}{$B_{4}$} & \multicolumn{2}{|c|}{$B_{4}$} & \multicolumn{2}{|c|}{$B_{4}$} \\
\hline Ranking order & \multicolumn{2}{|c|}{$B_{4} \succ B_{3} \succ B_{2}$} & \multicolumn{2}{|c|}{$B_{4} \succ B_{3} \succ B_{2}$} & \multicolumn{2}{|c|}{$B_{4} \succ B_{2} \succ B_{3}$} & \multicolumn{2}{|c|}{$B_{4} \succ B_{2} \succ B_{3}$} \\
\hline
\end{tabular}

Table 11. Ranking results obtained using different variants of TOPSIS method

\begin{tabular}{|c|c|c|c|c|c|c|c|c|}
\hline & \multicolumn{8}{|c|}{ Case II } \\
\hline & \multicolumn{2}{|c|}{ I } & \multicolumn{2}{|c|}{ II } & \multicolumn{2}{|c|}{ III } & \multicolumn{2}{|c|}{ IV } \\
\hline Normalization & \multicolumn{2}{|c|}{ Vector } & \multicolumn{2}{|c|}{ Vector } & \multicolumn{2}{|c|}{ MaxMin } & \multicolumn{2}{|c|}{ MaxMin } \\
\hline Distance metric & \multicolumn{2}{|c|}{ Euclidean } & \multicolumn{2}{|c|}{ City block } & \multicolumn{2}{|c|}{ Euclidean } & \multicolumn{2}{|c|}{ City block } \\
\hline Alternatives & $C_{i}$ & Rank & $C_{i}$ & Rank & $C_{i}$ & Rank & $C_{i}$ & Rank \\
\hline$B_{1}$ & 0.280 & 5 & 0.224 & 5 & 0.317 & 5 & 0.232 & 5 \\
\hline$B_{2}$ & 0.421 & 3 & 0.464 & 3 & 0.540 & 2 & 0.562 & 2 \\
\hline$B_{3}$ & 0.589 & 2 & 0.554 & 2 & 0.471 & 3 & 0.456 & 3 \\
\hline$B_{4}$ & 0.713 & 1 & 0.762 & 1 & 0.606 & 1 & 0.675 & 1 \\
\hline$B_{5}$ & 0.342 & 4 & 0.339 & 4 & 0.436 & 4 & 0.409 & 4 \\
\hline Best placed & \multicolumn{2}{|c|}{$B_{4}$} & \multicolumn{2}{|c|}{$B_{4}$} & \multicolumn{2}{|c|}{$B_{4}$} & \multicolumn{2}{|c|}{$B_{4}$} \\
\hline Ranking order & \multicolumn{2}{|c|}{$B_{4} \succ B_{3} \succ B_{2}$} & \multicolumn{2}{|c|}{$B_{4} \succ B_{3} \succ B_{2}$} & \multicolumn{2}{|c|}{$B_{4} \succ B_{2} \succ B_{3}$} & \multicolumn{2}{|c|}{$B_{4} \succ B_{2} \succ B_{3}$} \\
\hline
\end{tabular}


Compared with the same columns of Table 10, small changes in criteria weights do not have impact on the best placed alternative, and alternatives ranking orders.

Table 12 shows the summary results of ranking alternatives, which are obtained on the basis of use of different normalization procedures and different distance metrics.
In many scientific and professional journals, a number of papers have been devoted to comparison of some MCDM methods. Although research devoted to development and the usage of Fuzzy and/or Grey MCDM methods are currently more actual, the problem of selection of the most appropriate MCDM method is also actual.

Table 12. Ranking results obtained using different variants of TOPSIS method

\begin{tabular}{|c|c|c|c|c|}
\hline & I & II & III & IV \\
\hline Normalization & Vector & Vector & MaxMin & MaxMin \\
\hline Distance metric & Euclidean & City block & Euclidean & City block \\
\hline Case Study & $B_{4} \succ B_{2} \succ B_{1}$ & $B_{4} \succ B_{2} \succ B_{3}$ & $B_{2} \succ B_{4} \succ B_{5}$ & $B_{2} \succ B_{4} \succ B_{5}$ \\
\hline Case I & $B_{4} \succ B_{2} \succ B_{3}$ & $B_{4} \succ B_{3} \succ B_{2}$ & $B_{4} \succ B_{2} \succ B_{3}$ & $B_{4} \succ B_{2} \succ B_{3}$ \\
\hline Case II & $B_{4} \succ B_{3} \succ B_{2}$ & $B_{4} \succ B_{3} \succ B_{2}$ & $B_{4} \succ B_{2} \succ B_{3}$ & $B_{4} \succ B_{2} \succ B_{3}$ \\
\hline
\end{tabular}

From the above table, it can be concluded that the use of different normalization procedures and different distance metrics may have influence to the selection of the best ranked alternative and ranking order of alternatives.

\section{CONCLUSION}

Example considered in Case Study and its variations clearly indicate that, under certain circumstances, the use of different MCDM methods sometimes highlights different alternatives as the most appropriate alternative, as well as gives the different ranking order of alternatives.

Different aggregation procedures and different normalization procedures sometimes lead to the selection of different most acceptable alternatives.

At the same time, different relative weights of criteria, used in the decisionmaking model, can also have a significant impact on the selection of most appropriate alternatives, as well as ranking orders.
In this paper, we only highlighted some reasons which lead to different results, and indicate that different results obtained by different MCDM methods are not just a random event, but rather reality. We also emphasize that considered MCDM methods have their own specifics and advantages, which is why the choice of MCDM method may be a rather complex problem.

\section{References}

Aghajani, H., Sedaghat, M., Dargahi, H., Pourhossein, M. (2012). Applying VIKOR, TOPSIS and SAW in fuzzy environment for ranking suppliers in supply chain: A Case study. American Journal of Scientific Research, 48(1): 10-19.

Andre, F.J., Cardenete M.A., Romero, C. (2007). Using compromise programming for macroeconomic policy making in a general equilibrium framework: Theory andapplication to the Spanish economy. Journal of the Operational Research Society, 59(7): 875-883. 


\title{
УПОРЕДНА АНАЛИЗА НЕКИХ ЗНАЧАЈНИХ МЕТОДА ВИШЕКРИТЕРИЈУМСКОГ ОДЛУЧИВАҢА: ПРИМЕР РАНГИРАҢА СРПСКИХ БАНАКА
}

\author{
Драгиша Станујкић, Бојан Ђорђевић и Мира ђорђевић
}

\section{Извод}

У литератури су предложене бројне методе вишекритеријумског одлучивања. Такође је публикован и значајан број радова у којима је извршено поређење њихових карактеристика и перформанси. Међутим, коначан одговори на питања: која метода је најприкладнија и која метода је најефективнија су и даље актуелни. Због тога је у овом раду разматрана примена неких значајних метода вишекритеријумског одлучивања, на примеру рангирања српских банака. Циљ овог рада ипак није био одређивање најприкладније методе вишектитеријумског одлучивања за рангирање банака. Основни циљ овог рада је да се укаже на то да се коришћењем различитих метода вишекритеријумског одлучивања у појединим случајевима могу остварити различити редоследи рангираних алтернатива и такође истакне да различити резултати остварени применом појединих метода нису само случајност, већ реалност.

Кључне речи: "MCDM, SAW, MOORA, GRA, CP, VIKOR, TOPSIS"

Antucheviciene, J., Zakarevicius, A., based on interval-valued fuzzy sets. Applied Zavadskas, E.K. (2011). Measuring Soft Computing, 9(2): 457-461.

congruence of ranking results applying Bakshi, T., Sarkar, B. (2011). MCA based particular MCDM methods. Informatica 22(3): 319-338.

performance evaluation of project selection.

Antucheviciene, J., Zavadskas, E.K. (2012). Ranking redevelopment decisions of derelict buildings and analysis of ranking results. Economic Computation and International Journal of Software Engineering \& Applications (IJSEA), 2(2): 14-22.

Balezentis, A., Balezentis, T. (2011). Economic Cybernetics Studies and for Strategy Europe 2020: Diachronic Research, 46(2): 37-62.

Archana, M., Sujatha, V. (2012). Application of Fuzzy MOORA and GRA in Multi-criterion Decision Making Problems. International Journal of Computer Applications, 53(9): 46-50.

Arslan, M., Cunkas, M. (2012). Performance evaluation of sugar plants by fuzzy technique for order performance by similarity to ideal solution (TOPSIS). Cybernetics and Systems, 43(7): 529-548.

Ashtiani, B., Haghighirad, F., Makui, A. (2009). Extension of fuzzy TOPSIS method Analysis and Proposed Guidelines. Inzinerine Ekonomika-Engineering Economics, 22(3): 271-282.

Balezentis, A., Balezentis, T., Brauers W.K.M. (2012). MULTIMOORA-FG: A multi-objective decision making method for linguistic reasoning with an application to personnel selection. Informatica, 23(2): 173190.

Balezentis, A., Balezentis, T., Valkauskas, R. (2010). Evaluating situation of Lithuania in the European Union: structural indicators and MULTIMOORA method. Technological 
and Economic Development of Economy, 16(4): 578-602.

Banaitiene, N., Banaitis, A., Kaklauskas, A., Zavadskas, E.K. (2008). Evaluating the life cycle of a building: A multivariant and multiple criteria approach. Omega, 36(3): 429-441.

Bender, M.J., Simonovic, S.P. (2000). A fuzzy compromise approach to water resource systems planning under uncertainty. Fuzzy Sets and Systems, 115(1): 35-44.

Bilbao-Terol, A., Perez-Gladish, B., Arenas-Parra, M., Rodriguez-Uria, M.V. (2006). Fuzzy compromise programming for portfolio selection. Applied Mathematics and Computation, 173(1): 251-264.

Boran, F.E., Genc, S., Kurt, M., Akay, D. (2009). A multi-criteria intuitionistic fuzzy group decision making for supplier selection with TOPSIS method. Expert Systems with Applications, 36(8): 11363-11368.

Brans, J.P., Vincke, P. (1985). A preference ranking organization method: The PROMETHEE method for MCDM. Management Science, 31(6): 647-656.

Brauers, W.K.M. Ginevicius, R. (2009). Robustness in regional development studies. The case of Lithuania. Journal of Business Economics and Management, 10(2): 121140.

Brauers, W.K.M., Ginevicius, R. (2010). The economy of the Belgian regions tested with MULTIMOORA. Journal of Business Economics and Management, 11(2): 173209.

Brauers, W.K.M., Zavadskas, E.K. (2006). The MOORA method and its application to privatization in a transition economy. Control and Cybernetics, 35(2): 445-469.

Brauers, W.K.M., Zavadskas, E.K. (2009). Robustness of the multi-objective MOORA method with a test for the facilities sector. Technological and Economic Development of Economy, 15(2): 352-375.

Brauers, W.K.M., Zavadskas, E.K. (2010a). Project management by MULTIMOORA as an instrument for transition economies. Technological and Economic Development of Economy, 16(1): 5-24.

Brauers, W.K.M., Zavadskas, E.K. (2010b). Robustness in the MULTIMOORA model: the example of Tanzania. Transformations in Business \& Economics, 9(3): 67-83.

Brauers, W.K.M., Zavadskas, E.K. (2011). MULTIMOORA optimization used to decide on a bank loan to buy property. Technological and Economic Development of Economy, 17(1): 174-188.

Brauers, W.K.M., Zavadskas, E.K. (2012). Robustness of MULTIMOORA: A method for Multi-Objective Optimization. Informatica, 23(1): 1-25.

Brauers, W.K.M., Zavadskas, E.K., Turskis, Z., and Vilutiene, T. (2008). Multiobjective contractor's ranking by applying the MOORA method. Journal of Business Economics and Management, 9(4): 245-255.

Brauers, W.K.M., Balezentis, A., Balezentis, T. (2011). MULTIMOORA for the EU Member States updated with fuzzy number theory. Technological and Economic Development of Economy, 17(2): 273-304.

Brauers, W.K.M., Ginevicius, R., Podviezko, A. (2012). Evaluation of performance of Lithuanian commercial banks by multi-objective optimization. The 7th International Scientific Conference Business and Management 2012: Selected papers, Vilnius Gediminas Technical University, Faculty of Business Management, Vilnius, Lithuania. Vilnius: Technika, pp. 1042-1049.

Buyukuzkan, G. (2012). An integrated 
fuzzy multi-criteria group decision-making approach for green supplier evaluation. International Journal of Production Research, 50(11): 2892-2909.

Caterino, N., Iervolino, I., Manfredi, G., Cosenza, E. (2009). Comparative analysis of multi-criteria decision making methods for seismic structural retrofitting. Computer Aided Civil and Infrastructure Engineering, 24(6): 432-445.

Cehulic, D., Hunjak, T., Begicevic. N. (2011). Comparison of a bank's financial ratios using the analytical hierarchy process. In: Proceeding of the 22nd Central European conference on information and intelligent systems, University of Zagreb, Faculty of Organization and Informatics, Varazdin, Croatia, pp. 187-194.

Cetin, M.K., Cetin, E.I. (2010). MultiCriteria Analysis of Bank's Performances. International Journal of Economics and Finance Studies, 2(2): 73-78.

Chakraborty, S. (2011). Application of the MOORA method for decision making in manufacturing environment. The International Journal of Advanced Manufacturing Technology, 54(9-12): 11551166.

Chakraborty, S., Karande, P. (2012). Decision Making for Supplier Selection Using the MOORA Method. The IUP Journal of Operations Management, 11(2): 618.

Chan, J.W.K., Tong, T.K.L. (2007). Multicriteria material selections and end-of-life product strategy: Grey relational analysis approach. Materials \& Design, 28(5): 15391546.

Chang, C.H., Lin, J.J., Linc, J.H., Chiang, M.C. (2010). Domestic open-end equity mutual fund performance evaluation using extended TOPSIS method with different distance approaches. Expert Systems with
Applications, 37(6): 4642-4649.

Chatterjee, P., Chakraborty, S. (2012). Material selection using preferential ranking methods. Materials and Design, 35(4): 384393.

Chen, C.T. (2000). Extensions of the TOPSIS for group decision-making under fuzzy environment. Fuzzy sets and systems, 114(1): 1-9.

Chen, L.Y., Wang, T.C. (2009). Optimizing partners' choice in IS/IT outsourcing projects: The strategic decision of fuzzy VIKOR. International Journal of Production Economics, 120(1): 233-242.

Chen, T.Y. (2012). Comparative analysis of SAW and TOPSIS based on intervalvalued fuzzy sets: Discussions on score functions and weight constraints. Expert Systems with Applications, 39(2): 18481861.

Chiu, W.Y., Tzeng, G.H., Li, H.L. (2012). A new hybrid MCDM model combining DANP with VIKOR to improve e-store business. Knowledge-Based Systems, 37: 48-61.

Chou, S.Y., Chang, Y.H., Shen, C.Y. (2008). A fuzzy simple additive weighting system under group decision-making for facility location selection with objective/subjective attributes. European Journal of Operational Research, 189(1): 132-145.

Dagdeviren, M., Yavuz, S., Kilınc, N. (2009). Weapon selection using the AHP and TOPSIS methods under fuzzy environment. Expert Systems with Applications, 36(4): 8143-8151.

Deng, J.L. (1989). Introduction to grey system. Journal of Grey System, 1(1): 1-24.

Dey, B., Bairagi, B., Sarkar, B., Sanyal, S. (2012). A MOORA based fuzzy multicriteria decision making approach for supply chain strategy selection. International 
Journal of Industrial Engineering Computations, 3(4): 649-662.

Duckstein, L., Opricovic, S. (1980). Multiobjective optimization in river basin development. Water Resources Research, 16(1): 14-20.

Ertugrul, I., Karakasoglu, N. (2009). Performance evaluation of Turkish cement firms with fuzzy analytic hierarchy process and TOPSIS methods. Expert Systems with Applications, 36(1): 702-715.

Ferreira, F.A.F., Sharp W.R., Santos, P.S., Rodrigues M.M.P. (2012). Multiple Criteria Framework to Evaluate Bank Branch Potential Attractiveness. International Journal of Strategic Property Management, (3): 254-276.

Fouladgar, M.M., Yazdani-Chamzini, A., Zavadskas, E.K., Moini, S.H.H. (2012). A new hybrid model for evaluating the working strategies: case study of construction company. Technological and Economic Development of Economy, 18(1): 164-188.

$\mathrm{Fu}, \mathrm{C}$., Zheng, J., Zhao, J., Xu, W. (2001). Application of grey relational analysis for corrosion failure of oil tubes. Corrosion Science, 43(5): 881-889.

Fung, C.P. (2003). Manufacturing process optimization for wear property of fiberreinforced polybutylene terephthalate composites with grey relational analysis. Wear, 254(3): 298-306.

Ginevicius, R., Podvezko, V. (2008). Multicriteria evaluation of Lithuanian banks from the perspective of their reliability for clients. Journal of Business Economics and Management, 9(4): 257-267.

Ginevicius, R., Podvezko, V. (2009). Evaluating the Changes in Economic and Social Development of Lithuanian Countries by Multiple Criteria Methods. Technological and Economic Development of Economy, 15(3): 418-436.
Ginevicius, R., Podviezko, A. (2011). A framework of evaluation of commercial banks. Intelektine ekonomika - Intellectual economics, 1(9): 37-53.

Ginevicius, R., Podvezko, V., Raslanas, S. (2008). Evaluating the alternative solutions of wall insulation by multicriteria methods. Journal of Civil Engineering and Management, 14(4): 217-226.

Ginevicius, R., Brauers, W.K.M., and Podvezko, V. (2010a). Regional development in Lithuania considering multiple objectives by the MOORA method. Technological and Economic Development of Economy, 16(4): 613-640.

Ginevicius, R., Krivka, A., Simkunaite, J. (2010b). The model of forming competitive strategy of an enterprise under the conditions of oligopolic market. Journal of Business Economics and Management, 11(3): 367395.

Ginevicius, R., Podvezko, V., Novotny, M. (2010c). Evaluating Lithuanian banks from the perspective of their reliability to customers by PROMETHEE method. The 6th International Scientific Conference Business and Management 2010: selected papers, Vilnius Gediminas Technical University, Faculty of Business Management, Vilnius, Lithuania. Vilnius: Technika, pp. 993-999.

Huang, J.H., Peng, K.H. (2012). Fuzzy Rasch model in TOPSIS: A new approach for generating fuzzy numbers to assess the competitiveness of the tourism industries in Asian countries. Tourism Management, 33(2): 456-465.

Hunjak, T., Jakovcevic, D. (2001). AHP based model for bank performance evaluation and rating. In: Proceedings of 6th International Symposium on Analytic Hierarchy Process (ISAHP 2001), Berne, Switzerland, pp. 149-158. 
Hwang, C.L., Yoon, K. (1981). Multiple attribute decision making: Methods and applications. Springer New York.

Jahan, A., Mustapha, F., Ismail, M.Y., Sapuan, S.M., Bahraminasab, M. (2011). A comprehensive VIKOR method for material selection. Materials \& Design, 32(3): 12151221.

Jahanshahloo, G.R., Lotfi, F.H., Izadikhah, M. (2006). An algorithmic method to extend TOPSIS for decisionmaking problems with interval data. Applied mathematics and computation, 175(2): 13751384.

Kaklauskas, A., Zavadskas, E.K., Raslanas, S. (2005). Multivariant design and multiple criteria analysis of building refurbishments. Energy and Buildings, 37(4): 361-372.

Kaklauskas, A., Zavadskas, E.K., Raslanas, S., Ginevicius, R., Komka, A., Malinauskas, P. (2006). Selection of low-e windows in retrofit of public buildings by applying multiple criteria method COPRAS: A Lithuanian case. Energy and Buildings, 38(5): 454-462.

Kalibatas, D., and Turskis, Z. (2008). Multicriteria evaluation of inner climate by using MOORA method. Information technology and control, 37(1): 79-83.

Karande, P. and Chakraborty, S. (2012). A Fuzzy-MOORA approach for ERP system selection. Decision Sciences Letters, 1(1): 11-22.

Kaya, T., Kahraman, C. (2010). Multicriteria renewable energy planning using an integrated fuzzy VIKOR \& AHP methodology: The case of Istanbul. Energy, 35(6): 2517-2527.

Kersuliene V., Turskis Z. (2011). Integrated Fuzzy Multiple Criteria Decision Making Model for Architect Selection. Technological and Economic Development of Economy, 17(4): 645-666.

Kracka, M., Brauers, W.K.M., Zavadskas, E.K. (2010). Ranking heating losses in a building by applying the MULTIMOORA. Inzinerine Ekonomika-Engineering Economics, 21(4): 352-359.

Lin, C.L., Lin, J.L., Ko, T.C. (2002). Optimisation of the EDM process based on the orthogonal array with fuzzy logic and grey relational analysis method. The International Journal of Advanced Manufacturing Technology, 19(4): 271-277.

Liu, H.C., Liu, L., Liu, N., Mao, L.X. (2012). Risk evaluation in failure mode and effects analysis with extended VIKOR method under fuzzy environment. Expert Systems with Applications, 39(17): 1292612934.

MacCrimon, K.R. (1968). Decision Marking Among Multiple-Attribute Alternatives: a Survey and Consolidated Approach. RAND memorandum, RM-4823ARPA. The Rand Corporation, Santa Monica, California.

Madhuri, B.Ch., Chandulal, A. J., Padmaja, M. (2010). Selection of Best Web Site by Applying COPRAS-G Method. International Journal of Computer Science and Information Technologies, 1(2): 138146.

Mahdavi, I., Mahdavi-Amiri, N., Heidarzade, A., Nourifar, R. (2008). Designing a model of fuzzy TOPSIS in multiple criteria decision making. Applied Mathematics and Computation, 206(2): 607617.

Mazumdar, A., Datta, S., Makapatra, S.S. (2010). Multicriteria decision-making models for the evaluation and appraisal of teachers' performance. International Journal of Productivity and Quality Management, 6(2): 213-230.

Opricovic, S. (1998). Visekriterijumska 
optimizacija u građevinarstvu - Multi-criteria optimization of civil engineering systems. Faculty of Civil Engineering, Belgrade. (in Serbian).

Opricovic, S. (2007). A Fuzzy Compromise Solution for Multicriteria Problems. International Journal of Uncertainty, Fuzziness and KnowledgeBased Systems, 15(3): 363-380.

Opricovic, S. (2011). Fuzzy VIKOR with an application to water resources planning. Expert Systems with Applications, 38(10): 12983-12990.

Opricovic, S., Tzeng, G.H. (2004). Compromise solution by MCDM methods: A comparative analysis of VIKOR and TOPSIS. European Journal of Operational Research, 156(2): 445-455.

Podvezko, V. (2011). The comparative analysis of MCDA methods SAW and COPRAS. Inzinerine EkonomikaEngineering Economics, 22(2): 134-146.

Podvezko, V., Mitkus, S., Trinkuniene, E. (2010). Complex evaluation of contracts for construction. Journal of Civil Engineering and Management, 16(2): 287-297.

Poff, B.A., Tecle, A., Neary, D.G., Geils, B. (2010). Compromise Programming in forest management. Journal of the ArizonaNevada Academy of Science, 42(1): 44-60.

Popovic, G., Stanujkic, D., Stojanovic, S. (2012). Investment project selection by applying copras method and imprecise data. Serbian Journal of Management, 7(2): 257269.

Prodanovic, P., Simonovic, S.P. (2003). Fuzzy compromise programming for group decision making. IEEE Transactions on Systems Man and Cybernetics, Part A: Systems and Humans, 33(3): 358-365.

Rakocevic, S., Dragasevic. Z. (2009). Analysis of the Efficiency of Banks in Montenegro Using the AHP. In: Proceedings of the 10th International Symposium on the Analytic Hierarchy/Network Process: Multicriteria Decision Making (ISAHP 2009), University of Pittsburgh, Pittsburgh, Pennsylvania, USA, pp. 1-11.

Rao, R.V. (2008). A decision making methodology for material selection using an improved compromise ranking method. Materials \& Design, 29(10), 1949-1954.

Ravi, V. (2012). Selection of third-party reverse logistics providers for End-of-Life computers using TOPSIS-AHP based approach. International Journal of Logistics Systems and Management, 11(1): 24-37.

Roostaee, R., Izadikhah, M., Lotfi, F.H., Rostamy-Malkhalifeh, M. (2012). A MultiCriteria Intuitionistic Fuzzy Group Decision Making Method for Supplier Selection with VIKOR Method. International Journal of Fuzzy System Applications (IJFSA), 2(1): 117.

Roy, B. (1991). The Outranking Approach and the Foundation of ELECTRE Methods. Theory and Decision, 31(1): 49-73.

Saaty, T.L. (1980). Analytic Hierarchy Process: Planning, Priority Setting, Resource Allocation. McGraw-Hill, New York.

San Cristobal, J.R. (2011). Multi-criteria decision-making in the selection of a renewable energy project in spain: The Vikor method. Renewable energy, 36(2): 498-502.

Saremi, M., Mousavi, S.F., Sanayei, A. (2009). TQM consultant selection in SMEs with TOPSIS under fuzzy environment. Expert Systems with Application, 36(2): 2742-2749.

Savitha, K., Chandrasekar, C. (2011). Trusted network selection using SAW and TOPSIS algorithms for heterogeneous wireless networks. International Journal of Computer Applications, 26(8): 22-29.

Sayadi, M.K., Heydari, M., Shahanaghi, K. (2009). Extension of VIKOR method for 
decision making problem with interval numbers. Applied Mathematical Modelling, 33(5): 2257-2262.

Shanian, A., Savadogo O. (2006). TOPSIS multiple-criteria decision support analysis for material selection of metallic bipolar plates for polymer electrolyte fuel cell. Journal of Power Sources, 159(2): 1095-1104.

Sherman, H.D., Gold, F. (1985). Bank Branch operating Efficiency: Evaluation with Data Envelopment Analysis. Journal of Banking and Finance, 9(2): 279-315.

Shih, H.S., Shyur, H.J., Lee, E.S. (2007). An extension of TOPSIS for group decision making. Mathematical and Computer Modelling, 45(7): 801-813.

Simonovic, S.P., Burn, D.H. (1989). An improved methodology for short-term operation of a single multipurpose reservoir. Water Resources Research, 25(1): 1-8.

Simonovic, S.P., Venema, H.D., Burn, D.H. (1992). Risk-based parameter selection for short-term reservoir operation. Journal of Hydrology, 131(1-4): 269-291.

Stankeviciene, J., Mencaite, E. (2012). The evaluation of bank performance using multicriteria decision making model: a case study on Lithuanian commercial banks. Technological and Economic Development of Economy, 18(1): 189-205.

Stanujkic, D., Magdalinovic, N., Jovanovic, R., Stojanovic, S. (2012a). An objective multi-criteria approach to optimization using MOORA method and interval grey numbers. Technological and Economic Development of Economy, 18(2): 331-363.

Stanujkic, D., Magdalinovic, N., Stojanovic, S., Jovanovic, R. (2012b). Extension of ratio system part of MOORA method for solving decision-making problems with interval data. Informatica,
23(1): 141-154.

Susinska, S., Zavadskas, E.K., Turskis, Z. (2011). Multiple criteria assessment of pilecolumns alternatives. Baltic Journal of Road and Bridge Engineering, 6(3): 145-152.

Tansel, Y. (2012). An experimental design approach using TOPSIS method for the selection of computer-integrated manufacturing technologies. Robotics and Computer-Integrated Manufacturing 28(2): 245-256.

Tecle, A., Shrestha, B.P., Duckstein, L. (1998). A multiobjective decision support system for multiresource forest management. Group Decision and Negotiation, 7(1): 2340.

Tong, L.I., Chen, C.C., Wang, C.H. (2007). Optimization of multi-response processes using the VIKOR method. International Journal of Advanced Manufacturing Technology, 31(11): 10491057.

Tosun, N. (2006). Determination of optimum parameters for multi-performance characteristics in drilling by using grey relational analysis. The International Journal of Advanced Manufacturing Technology, 28(5): 450-455.

Triantaphyllou, E. (2000). Multi-criteria decision making methods: A comparative study. Kluwer academic publishers, Applied optimization series, (Vol. 44).

Turskis, Z., Tamosaitiene, J., Vilutiene, T., Zavadskas, E.K. (2010). Contractor selection for construction works by applying SAW-G and TOPSIS grey techniques. Journal of Business Economics and Management, 11(1): 34-55.

Turskis, Z., Zavadskas, E.K. (2010a). A novel method for Multiple Criteria Analysis: Grey Additive Ratio Assessment (ARAS-G) method, Informatica 21(4): 597-610.

Turskis, Z., Zavadskas, E.K. (2010b). A 
new fuzzy Additive Ratio ASsessment method (ARAS-F). case study: the analysis of fuzzy multiple criteria in order to select the logistic centers location. Transport 25(4): 423-432.

Turskis, Z., Lazauskas, M., Zavadskas, E.K. (2012). Fuzzy Multiple Criteria Assessment of Construction Site Alternatives for Non-Hazardous Waste Incineration Plant in Vilnius City, Applying ARAS-F and AHP Methods. Journal of Environmental Engineering and Landscape Management, 20(2): 110-120.

Wang, T.C., Chang, T.H. (2007). Application of TOPSIS in evaluating initial training aircraft under a fuzzy environment. Expert Systems with Applications, 33(4): 870-880.

Wang, Y.M., Elhag, T. (2006). Fuzzy TOPSIS method based on alpha level sets with an application to bridge risk assessment. Expert Systems with Applications, 31(2): 309-319.

Wu, C.C., Chang, N.B. (2004). Corporate optimal production planning with varying environmental costs: A grey compromise programming approach. European Journal of Operational Research, 155(1): 68-95.

Wu, H.Y., Tzeng, G.H., Chen, Y.H. (2009). A fuzzy MCDM approach for evaluating banking performance based on Balanced Scorecard. Expert Systems with Applications, 36(6): 10135-10147.

Yang, T., Hung, C.C. (2007). Multipleattribute decision making methods for plant layout design problem. Robotics and Computer-Integrated Manufacturing, 23(1): 126-137.

Yeh, Q.J. (1996). The application of data envelopment analysis in conjunction with financial ratios for bank performance evaluation. Journal of the Operational Research Society, 47(8): 980-988.
Yoon, K., Hwang, C.L. (1980). Multiple Attribute Decision - Making Methods and Applications: A State of the Art Survey. Springer Verlag, Berlin.

Yu, P.L. (1973). A Class of Solutions for Group Decision Problems. Management Science 19(8): 936-946.

Yu-Ping, O.Y., Shieh, H.M., Leu, J.D., Tzeng, G.H. (2009). A VIKOR-based multiple criteria decision method for improving information security risk. International Journal of Information Technology \& Decision Making, 8(2): 267287.

Zavadskas, E.K., Antucheviciene, J. (2007). Multiple criteria evaluation of rural building's regeneration alternatives. Building and Environment, 42(1): 436-451.

Zavadskas, E.K., Turskis, Z. (2008). A new logarithmic normalization method in games theory. Informatica, 19(2): 303-314.

Zavadskas, E.K., Turskis, Z. (2010). A new additive ratio assessment (ARAS) method in multicriteria decision-making. Technological and Economic Development of Economy, 16 (2): 159-172.

Zavadskas, E.K., Kaklauskas, A., Sarka, V. (1994). The new method of multicriteria complex proportional assessment of projects. Technological and Economic Development of Economy, 1(3): 131-139.

Zavadskas, E.K., Kaklauskas, A., Kvederyte, N. (2001). Multivariant design and multiple criteria analysis of building life cycle. Informatica, 12(1): 169-188.

Zavadskas, E.K., Kaklauskas, A., Banaitis, A., Kvederyte, N. (2004). Housing credit access model: The case for Lithuania. European Journal of Operational Research, 155(2): 335-352.

Zavadskas, E.K., Kaklauskas, A., Turskis, Z., Tamosaitiene, J. (2008a). Selection of the effective dwelling house walls applying 
attributes determined in intervals. Journal of Civil Engineering and Management, 14(2): 85-93.

Zavadskas, E.K., Turskis, Z., Tamosaitiene, J., Marina, V. (2008b). Multicriteria selection of projet managers by applying grey criteria. Technological and Economic Development of Economy, 14(4): 462-477.

Zavadskas, E.K., Z. Turskis and J. Tamosaitiene (2008c). Contractor selection of construction in a competitive environment. Journal of Business Economics and Management, 9(3): 181-187.

Zavadskas, E.K., Turskis, Z., Tamosaitiene, J. (2010a). Risk assessment of construction projects. Journal of Civil Engineering and Management, 16(1): 33-46. Zavadskas, E.K., Vilutiene, T., Turskis Z., Tamosaitiene, J. (2010b). Contractor selection for construction works by applying SAW-G and TOPSIS grey techniques. Journal of Business Economics and Management, 11(1): 34-55.

Zavadskas, E.K., Kaklauskas, A., Turskis, Z., Tamosaitiene, J., Kalibatas, D. (2011). Assessment of the indoor applying the COPRAS-G Method: Lithuanian Case Study. Environmental Engineering and Management Journal, 10(5): 637-647.

Zavadskas, E.K., Vainiunas, P., Turskis, Z., Tamosaitiene, J. (2012). Multiple criteria decision support system for assessment of projects managers in construction. International Journal of Information Technology \& Decision Making, 11(2): 501520.

Zeleny, M. (1973). Compromise programming. In: Multiple Criteria Decision Making, eds: J. Cochrane L. \& M. Zeleny, pp. 262-301, University of South Carolina Press, Columbia, SC.

Zolfani, S.H., Sedaghat, M., Zavadskas,
E.K. (2012). Performance evaluating of rural ICT centers (telecenters), applying fuzzy AHP, SAW-G and TOPSIS Grey, a case study in Iran. Technological and Economic Development of Economy, 18(2): 364-387. 